\title{
An explorative approach to the cross- section of international migration and sexual preference: same-sex couples in Germany
}

\author{
Mirko K. Braack ${ }^{*}$ and Nadja Milewski
}

* Correspondence: mirko.braack@ uni-rostock.de

Institute of Sociology and Demography, University of Rostock, Ulmenstraße 69, 18055 Rostock, Germany

\begin{abstract}
We study the intersection of international migration and sexual preference from a socio-demographic perspective by looking at same-sex couples among migrants in Germany. Despite increasing ethnic diversity and greater social and legal liberality toward non-normative living arrangements, there are hardly any available quantitative data on this vulnerable group, which crosses two social boundaries. Drawing on the scientific-use file of the German Microcensus (2013), we estimate the prevalence of same-sex couples among female and male migrants, and describe their socio-demographic characteristics. We use different approaches to imputing data to account for the possibility that the reported information on same-sex relationships may be missing or wrong, and consider different definitions of "migrant status". Our results show that the share of couples who were same-sex was smaller among the immigrant ( 0.2 to $1.4 \%$ ) than among the native population (0.6 to $2.0 \%$ ). Moreover, migrants in a same-sex couple were more similar in terms of other sociodemographic variables (age, education) to natives in a same-sex union than to migrants in an opposite-sex union. This study contributes to the LGBT social science literature by providing the first quantitative description of this minority-in-a minority group in Germany.
\end{abstract}

Keywords: Same-sex unions, Social boundaries, Immigration, Microcensus

\section{Research question and motivation: studying a minority in a minority}

In recent years, the heterogeneity of populations in Europe has increased as a result of continuing immigration (Coleman, 2006; Van Mol and de Valk, 2016). Across the EU member states, the share of foreign citizens (i.e., persons holding citizenship of a nonmember state) in the population recently grew to $4.4 \%$ (Eurostat, 2016). In Germany, the leading receiving country in Europe, more than $20 \%$ of the population are firstgeneration immigrants or their descendants. The main countries of origin of migrants in Germany are Turkey, Poland, Russia, Romania, and Italy, which constitute about $40 \%$ of the migrant population (Destatis, 2018).

(c) The Author(s). 2020 Open Access This article is licensed under a Creative Commons Attribution 4.0 International License, which permits use, sharing, adaptation, distribution and reproduction in any medium or format, as long as you give appropriate credit to the original author(s) and the source, provide a link to the Creative Commons licence, and indicate if changes were made. The images or other third party material in this article are included in the article's Creative Commons licence, unless indicated otherwise in a credit line to the material. If material is not included in the article's Creative Commons licence and your intended use is not permitted by statutory regulation or exceeds the permitted use, you will need to obtain permission directly from the copyright holder. To view a copy of this licence, visit http://creativecommons.org/licenses/by/4.0/. 
In the previous decades, developments that are frequently said to reflect the second demographic transition (van de Kaa, 1987) have occurred. These changes in union formation patterns have led to a pluralization of living arrangements (Lengerer and Klein, 2007; Wagner and Valdés Cifuentes, 2014), as well as to trends toward individualization (Beck and Beck-Gernsheim, 2005) and de-institutionalization (Cherlin, 2004; Lauer and Yodanis, 2010). These developments have been accompanied, if not preceded, by substantial changes in values (Inglehart, 1997; Inglehart and Norris, 2003) regarding sexual liberalization, marriage, and family. At the same time, marriage and family laws have changed in many western European countries (Waaldijk, 2020), with non-normative living arrangements gradually being legally recognized. Individuals living in such arrangements have become less disadvantaged relative to people in an oppositesex married union (Kollman, 2013). In this study, we concentrate on the intersection of two minority groups, both of whom are at risk of experiencing social disadvantages and "othering processes": namely, international migrants and individuals living in a same-sex union.

In Germany, homosexuality was illegal until the 1960s, when it was decriminalized. In 2001, same-sex couples got the right to register their partnership as "eingetragene Lebenspartnerschaft" and stepwisely these unions became legally equal to married couples. Since the autumn of 2017, same-sex couples have had the right to marry (Gürbüz, 2016). As the societal climates of western countries have changed, the numbers of native-born same-sex couples reported in statistical sources have been increasing (Lengerer and Bohr, 2019a). However, these unions make up only a small share of all couples in Germany (Lengerer and Bohr, 2019b; Rupp and Haag, 2016). Depending on the definitions and the concepts used to identify them in the data, the share of same-sex couples in Germany is between 0.5\% and 1.1\% (Kroh et al. 2017; Lengerer and Bohr, 2019a).

Therefore, while same-sex unions are now "legal" in western European contexts, they are (still) expressions of "non-normative," "unconventional," and "non-standard" lifestyles; and thus challenge family norms (Franchi and Selmi, 2020; Thibeaud, 2020). Research on individual attitudes toward homosexuality shows considerable variation between countries as well as inside countries, with significant shares of people rejecting same-sex behavior completely (Inglehart and Norris, 2003: p. 60). Therefore, individuals belonging to any sexual minority often report experiencing discrimination and threats (Steffens and Wagner, 2009; FRA, 2014), issues surrounding same-sex preferences and behaviors are seen as sensitive.

The intersection of international migration and sexual preference is an aspect that received little attention in previous studies on the demographic behavior of immigrants, which primarily applied the classical assimilation perspective, and looked at whether immigrants adapt over generations to the majority population at destination; i.e., to a heterosexual, mainstream population. This may be in part because many immigrant groups in Europe originate from countries where non-normative expressions of sexuality are hidden, forbidden, and/or subject to sanctions. From a quantitative perspective, this topic may not appear to be important, given that the potential "target population" is assumed to be very small. In addition, like information on international migration of individuals or their descendants in general, the reliability of the data that do exist may be limited (Nowok et al. 2006), and data 
on this minority within a minority are hardly available (Andersson et al. 2006). For these reasons, we acknowledge that our study is of an explanatory and descriptive nature.

Our study is motivated by the concept of social-boundary crossing (Lamont and Molnár, 2002). Chamie and Mirkin (2011) emphasized that a same-sex union "is more than a private matter between two individuals" (Chamie and Mirkin, 2011, p. 544) because it reflects the relationship between majorities and minorities. Our aim is to study the intersection of international migration and sexual preference by first estimating the prevalence of same-sex couples among international migrants in Germany, and then describing their patterns and correlates. To better explain the findings from a theoretical perspective, we compare them to findings on same-sex couples of German natives and on opposite-sex migrant couples. In particular, we look at exogamy as a form of boundary crossing in mate selection. We will compare these couples to couples who are exogamous with respect to national origin, as such "mixed" couples are also subject to "othering" processes and social exclusion. Steinbugler (2005) described the ambivalent relationship of same-sex unions and mixed unions, showing that affirmation and harassment may lie close together. We take these considerations into account in the next section, and carve out the intersection of international migration and sexual behavior in Germany by linking same-sex unions, boundary crossing, and exogamy. In the third section, we introduce our dataset and explain the method to calculate boundary estimates suggested by Lengerer and Bohr (2019a) to identify same-sex couples in the German Microcensus. In the fourth section, we present our results. In the fifth and concluding section, we discuss our findings.

\section{Theoretical background and context}

\section{Social boundary crossing in mate selection}

In any overview of same-sex unions and the role of migration, the concept of social and symbolic boundaries is important. Lamont and Molnár (2002) mentioned two types of boundaries that affect individual and group identity: symbolic and social. Symbolic boundaries are used to classify and group people, who are divided into a societal "us" and "them"; while "[s]ocial boundaries are objectified forms of social differences manifested in unequal access to and unequal distribution of resources" (Lamont and Molnár, 2002, p. 168). Natives as well as migrants can use these differences to distinguish themselves and to build up boundaries between groups in order to strengthen their own identity; whereas crossing these boundaries can be a strategy for adapting to the host society (Bail, 2008). These boundaries can also be sources of conflict that complicate the contact and the partner choices of immigrants and natives (Alba, 2005).

Partner choice has been characterized as the product of three major prerequisites: individual preferences, opportunity structures, and third-party influence (Kalmijn, 1998). Most of the previous literature on determinants of partner choice on the micro level has been based on the household economics and the economics of marriage (Becker, 1973), which postulates that partner choice is a function of the individual's attempt to maximize his/her outcomes. An individual may prefer 
that his/her partner is similar to him/herself with respect to certain traits (such as education), but different from him/herself with respect to others (such as task division). Preference theory suggests that having similar social backgrounds and value systems would tend to reduce potential conflicts, and, as a consequence, that endogamous partner choice occurs more often than exogamy. Research on the role of third parties in partner choice has pointed in the same direction. It has been argued that exogamy is the result of status exchange, and this hypothesis is frequently mentioned in the context of the partner choices of international migrants. According to this hypothesis, (native) individuals search a partner with a higher education, a younger age, or other attributes related to more "reproductive potential" and exchange it with a partner with a more secure residence status or an entry ticket to the destination country. According to the classical assimilation hypothesis, immigrant exogamy is both a means and a result of immigrants' adaptation to the host country (Alba and Nee, 1997; Gordon, 1964).

However, from the perspective of immigrants, exogamy appears to be a nonnormative, deviating behavior. When individuals were asked about their preferences in terms of their own partner choice or that of their children, out-marriage was not the dominant partner choice (Carol, 2013; Huijnk and Liefbroer, 2012). In some minority groups, exogamy can result in social exclusion or it can negatively impact the quality of family and other social contacts (Huijnk et al., 2010). Previous research has found that exogamy among immigrants is associated on the individual level with higher education, higher age, and higher-order unions; as well as with greater dissimilarities between the spouses with respect to age, education, religion, or other characteristics (Celikaksoy et al. 2010; Fitzpatrick et al. 2009; González-Ferrer et al. 2018; Kalmijn, 1998; Kulu and Hannemann 2019; Troy et al. 2006). These findings suggest that, on the one hand, exogamy may be a "second choice" that is made when individuals "cast a wider net" after searching for a longer time. But on the other hand, these results indicate that such non-normative behavior may be chosen by individuals who have more human capital, and who are therefore better able to cope with the (possibly negative) consequences of their partner choice.

However, classical theories of household economics and marriage do not consider sexual preferences. Based on the idea of the natural production of offspring as a household commodity, these theories presume that a married couple (or a couple household) consists of a "man" and a "woman". Thus, "mixedness" with respect to the sex of the partners is not seen as the exception, but as the rule. This is due to the persistence of an ideology of heterosexism and sexual prejudices in which homosexuality is stigmatized, which can lead to discrimination and violence (Herek et al. 2007). Any "other" scenario of mixedness must be explained, as we will note in the next sections. Lengerer and Bohr (2019a) considered same-sex unions not only from the perspective of pluralized ways of life or sexual preferences, but added these unions to classical approaches of mate selection. They showed how sociocultural changes (e.g., more tolerance and legal conditions) as well as structural contexts (e.g., the visibility of $\mathrm{LGBT}^{1}$ people and new options for meeting potential partners through the internet) influence people's opportunities to form a same-sex union.

${ }^{1}$ Lesbian, gay, bisexual, and transgender (LGBT) 
Therefore, in a global perspective, same-sex unions reflect societal and institutional changes regarding mate selection and liberalization (Chamie and Mirkin, 2011). As well as changing classical theoretical approaches regarding union formation and research practices, the emergence of same-sex unions has brought attention to issues of sexual preferences and behavior, as well as of the living conditions of LGBT individuals (Serrano Amaya and Rios Gonzàlez, 2019).

\section{Sexual preferences, sexual behavior, and social attitudes toward same-sex unions}

While sexual preferences appear to be a prerequisite for partner choice, the recent literature has shown that such preferences are not stable in the life course, and are not a linear or a general process (Kitzinger and Wilkinson, 1995; Lengerer and Bohr, 2019a, p. 140). Instead, it has been argued that "sexual and gender identity formation is a highly individual process" (Eliason and Schope, 2007, p. 23). Kertzner (2007) observed that the development of sexual preferences does not end in adulthood, as some individuals who may have previously been part of an opposite-sex couple do not start to realize their same-sex interest until later in life. Additionally, the experience of being stigmatized while young may affect the later life narratives and the structures of the lives of adults, because there are "greater proportions of single and childless adults, different configurations of family life and different relationship dynamics" (Kertzner, 2007, p. 54) among same-sex couples than there are among opposite-sex couples.

However, people's sexual behavior may not coincide with their sexual preferences, especially if the behavior is non-normative. In this context, opportunity structures and legal conditions become increasingly important. In recent years, the legal conditions surrounding same-sex unions have changed, especially in the European Union and the USA. Yet, these trends have not been universal or simultaneous. There are still differences between countries in terms of the extent to which they recognize diversity in sexual identities and behavior. However, as a consequence of anti-discrimination efforts in the European Union, as well as of identity politics and increased recognition of minorities of all kinds, policies designed to protect the opposite-sex family model have, in recent years, been transformed into policies that respect all family and couple forms equally (Kollmann 2013, p. 11-15). The previous literature has shown that the number of same-sex couples registered in several European countries increased after legal conditions were liberalized (for Sweden and Norway Andersson et al. 2006; for Sweden Kolk and Andersson, 2020; for Germany Lengerer and Bohr, 2019a). But it is important to note that despite this liberalization, which extended greater tolerance to younger cohorts in particular, LGBT people have continued to be exposed to a societal climate in which they experience stress and discrimination (Meyer, 2007). LGBT people in Europe, and younger cohorts and lesbian women in particular, have reported being harassed because of their sexual identity or behavior. Moreover, LGBT people, especially gay men and transgender people, are more frequently affected by violence (FRA, 2014). This societal climate of tolerance or rejection of homosexuality affects not only the individuals in a same-sex union, but people's attitudes (irrespective of their own sexual identity or preference). These attitudes can be transmitted through, for example, political socialization via media (Almond and Verba, 1989; 
Ayoub and Garretson, 2017), religious discourses (Adamczyk and Pitt, 2009; Adamczyk et al. 2016), or legal conditions (Brumbaugh et al. 2008; Kollmann, 2013). Further predictors of tolerance for same-sex unions are not just religiosity, religious affiliation, and socioeconomic position (especially for those who gain the most from economic development (Andersen and Fetner, 2008)); but gender, age, family status, regional aspects, and the number of LGBT people in a person's own network (Steffens and Wagner, 2004).

\section{The intersection of being in a same-sex union and a migrant}

Under the lenses of boundary crossing, same-sex unions can be compared to exogamous opposite-sex unions. Both challenge ideas of belonging and can lead people in a same-sex union as well as in a mixed-union to evolve coping strategies (Lamont and Mizrachi, 2012). Further similarities can be found. In line with research on mixed marriages with respect to migrant background, research on same-sex non-migrant couples has shown that in western Germany, choosing a same-sex partner is associated with having a higher education, being younger, and living in an urban region (Lengerer \& Bohr 2019b). Additionally, a study for Germany by Kroh et al. (2017) showed that compared to heterosexual people, LGBT people are less likely to work in the production industry or transport or logistic sectors, had lower incomes, and were more likely to be dissatisfied with life in general. These findings are comparable to results for other western contexts, like the USA (Black et al. 2000).

While there appear to be similarities in the regulations and attitudes regarding migration and same-sex unions among international migrants in Europe (Haider-Markel and Joslyn, 2005), the question of same-sex unions among these migrant groups has hardly been raised. A small number of studies have found an association between citizenship, access to residence status in Europe, and LGBT migrants, with special attention being paid to mixed unions (Chauvin et al. 2019; Fassin and Salcedo, 2015). Moreover, there have been a handful of papers on attitudes toward homosexuality, which showed that, on the one hand, immigrants are more likely than European natives to express opposition to homosexuality (Röder, 2015); and, on the other hand, that migrants are more open to homosexuality than their stayer counterparts in their respective countries of origin (Soehl, 2017).

Furthermore, Inglehart and Norris (2003, p. 62) showed that sexual liberalization in postindustrial countries is associated with more tolerant social attitudes not only about homosexuality, but also about other sensitive issues such as divorce, abortion, or prostitution. They showed that while the differences in attitudes toward homosexuality between postindustrial and industrial countries are large, the differences between postindustrial and agrarian countries are even larger. However, their results also indicated that, although there are large differences between societies with a Muslim minority and societies with a Muslim majority, these differences did not continue based on the presence of migrants in a host society. Rather, they found, Muslim migrants in European countries have values regarding sexual liberalization that are somewhere in the middle of those in their country of origin and their host society, and seem to adopt the values of their host society over the time (Norris and Inglehart, 2012; Soehl, 2017). 
In a more global context, it is known that individuals sometimes migrate in order to escape prejudice and discrimination in their country of origin by moving to a more tolerant host country where they can engage in sexual behavior more freely. Nevertheless, there is almost no research on the consequences of immigration for LGBT people (Carrillo, 2004). Indeed, it has long been assumed "that migrants are heterosexuals (or on their way to becoming so) and queers are citizens (even though second-class ones)" (Luibhéid, 2008, p. 169). Hence, less is known about the behavioral dimension of samesex couples in migrant groups. Ramirez-Valles (2007) showed in a research overview for Latino men in the USA how being at the intersection of an ethnic and a sexual minority can lead people to feel that they are different and less valued than members of the majority groups. People with these intersectional identities may be at higher risk of poverty, unemployment, depression, and violence. The living conditions of LGBT people differ across cultural contexts, and their sexual identities and behavior are subject to different norms (Padilla et al. 2007). Thus, while migration can enable LGBT people to gain more sexual freedom and to liberate themselves from the discrimination and stigma they faced in their country of origin and family contexts, it can also expose them to ongoing discrimination. In the host country context of the USA for example, LGBT migrants may experience discrimination because of both their sexual behavior and their migrant status (Vasquez del Aguila, 2012). There is evidence that LGBT refugees who came to Germany are having similar experiences. While these refugees are able to live out their sexual identity, they also face discrimination and are at higher risk of mental illness (Golembe et al. 2019). While the research results on the situations of LGBT migrants have been ambiguous, there is a lack of quantitative knowledge about same-sex couples, which we focus on with our research hypotheses.

\section{Working hypotheses}

The working hypotheses guiding our study consist of three parts. First, we compare the prevalence of same-sex couples among migrants and non-migrants. For example, as many immigrant groups in Germany originate from countries where laws and attitudes regarding same-sex unions are less liberal than they are in Germany, we assume that the percentage of individuals in same-sex couples was lower among immigrants than among natives, but also that there may be some variation depending on whether an individual had a European or a non-European country of origin. This may be the case because of different and smaller partner markets for migrants, because of originating from countries with negative laws and attitudes regarding same-sex unions (H1).

We further examine the possibility of a double boundary crossing, and that the intersection of being in a sexual minority, while at the same time belonging to an ethnic minority, may lead to more social contacts within the sexual minority in the majority population in Germany. Hence, for migrants, the likelihood of being in an exogamous union may be greater in same-sex couples than in opposite-sex couples (H2).

The second part of our research is on the patterns of people in same-sex unions. Thus, we study the individual patterns and couple characteristics of same-sex couples. In line with previous research on non-normative partner choice, we assume that compared to their heterosexual counterparts, individuals who were in a same-sex union were younger, better educated, and more likely to be in full- or part-time employment 
(H3a). Based on previous research on exogamous partner choice, we further assume that same-sex couples were less similar in terms of age and education than other migrant couples (H3b).

\section{Data and methods}

We use the scientific-use file of the German Microcensus for the year 2013 (Destatis, 2014; RDC, 2013). The Microcensus is a sample that is representative of the resident population in Germany. We excluded single households and all respondents who had no partner-or whose partner status was not valid, and thus could not have been in a same-sex union-as well as all children living in the household. Consequently, our analytical sample contains only individuals aged 18-70 who were in a marital or nonmarital opposite-sex or same-sex union.

The identification of a union in the Microcensus was a stepwise process. While Microcensus respondents were required to answer some questions, the questions about union and partnership status were optional. First, the respondent was asked whether s/ he was sharing his/her household with a partner. In a second step, the respondent was asked whether $\mathrm{s} / \mathrm{he}$ was married. If the person said $\mathrm{s} / \mathrm{he}$ was not married, $\mathrm{s} / \mathrm{he}$ was asked whether s/he was in a non-marital union. Thus, the Microcensus provides information about the institutionalization of unions among married and non-married sameand opposite-sex couples (Lengerer and Klein, 2007, p. 436-440; Lengerer \& Bohr, 2019a, p. 143).

There has been a broad discussion about whether and, if so, how it is possible to identify LGBT people and same-sex unions in survey or census data. Because the target group is small, census data are favored sources. However, such data are limited because they lack many of the details that are used in defining same-sex unions (Cortina and Festy, 2014; Festy, 2007; Phua and Kaufman, 1999). Moreover, in both census and survey data, the behavior and partnership dimensions covered vary. For example, some surveys ask respondents about their same-sex experiences or preferences, while others ask respondents whether they are in a same-sex relationship (Gates, 2011; Geary et al. 2018). In addition, when respondents fail to answer such questions (Goldani et al. 2013) or provide wrong answers-by, for example, pretending that a partner is a roommate (Gates, 2010) or miscoding the sexes of the partners-the number of same-sex unions may be undercounted (Banens and Le Penven, 2016; Régnier-Loilier, 2018). In the construction of our sample, we took into account the possibility that the respondents did not answer the questions or gave wrong answers.

We follow a procedure used by Lengerer and Bohr (2019a), who suggested working with a range of results. Our lower boundary of the prevalence of same-sex unions was formed by the respondents who indicated that they were sharing a household with a partner, and that this household was their main residence; and who clearly identified the partner as their intimate partner. The sample constructed on this basis contained 158,762 individuals, of whom about 904 were in a samesex couple ( $30 \%$ have registered their union in this sample). In the second step, we added the respondents who reported the household in the Microcensus as a secondary residence, as well as those who said that they were married, but did not permanently share a household with their partner. Given that our aim is to study 
international migrants, we thought that this approach was necessary, because previous literature on migrant families has shown that they may experience temporary periods of spatial separation. The sample constructed on this basis contained 163, 210 individuals, of whom about 993 were in a same-sex couple. Next, we enlarged the sample to include a category of individuals who did not answer the question on the nature of the relationship. If the partner in the household was of the same sex and the respondent did not answer the question about whether the partner was living in the household, the household was categorized as same-sex. The sample constructed on this basis contained 163,229 individuals in a union, of whom about 997 were in a same-sex couple. The last step added the households for whom the composition of the household suggested that they were a same-sex couple; i.e., the household consisted of two people of the same sex who were not related to each other. The sample constructed on this basis contained 165,318 individuals in a union, of whom about 3084 were in a same-sex couple. The last sample sets the upper boundary of the range of same-sex couples and may overestimate the number of same-sex unions, because it could include persons living together without an intimate relationship

Similarly, we also worked with the variable "migrant status" with different definitions of the group, and created lower and upper boundaries to estimate the percentage of "migrants" in a same-sex union. In order to distinguish between different "migrant statuses," we used differences in citizenship and migration experiences: our lower boundary-i.e., the smallest "migrant" group-was formed by first-generation migrants who are non-German citizens. We then added individuals who immigrated to Germany and became German citizens (including so-called ethnic Germans from Eastern Europe), and individuals who belong to the second migrant generation and are non-citizens. Our most inclusive/biggest migrant group also includes the second generation with German citizenship. Our upper boundary corresponds to the current definition in German official statistics of "migrant background," according to which a "migrant" is a person who was either not born in Germany and who moved to Germany from abroad, or who was born as a child of at least one parent or who has a grandparent who was not born in Germany or as a German citizen (Destatis, 2018: p. 4). The "migrants"' regions of origin were grouped as follows: countries of the European Union and the Schengen Area, which were member states before the enlargements of the Union in the 2000s; countries that are new member states; and all other European countries, as well as the Russian Federation, the Middle East and North Africa (MENA) region, Asia, and all other countries that could not be distinguished in more detail in the data.

Our analyses are mainly descriptive using bivariate statistics, estimating chi-square distribution tests for the migrants in same- and opposite-sex unions. First, we address the comparison between migrants and natives by calculating percentages of individuals in same-sex couples as the total number of individuals in couples in the respective group, separately for migrants and natives. Additionally, we estimate the percentages of migrants and natives in same-sex unions by migrant status. Second, we compare samesex and opposite-sex couples based on their exogamy in terms of migrant status. Third, in order to identify the characteristics of same-sex couples, we exclude the native opposite-sex couples from the sample. We then compare same-sex couples of migrants 
with other migrant couples and with "native" same-sex couples. In our analyses on the individual characteristics of same-sex couples, we compare women and men (age, education, occupational status, region of origin, citizenship). Finally, we look at the couple characteristics; i.e., the relative ages and educational levels of the partners, and whether children were living in the couple's household. The bivariate statistics are based on the upper boundary of same-sex couples. We repeated the same analyses for the sample corresponding to the lower boundary of same-sex couples, and found similar distributions.

In a final step, we estimate a multivariate logistic regression model, with being in a same-sex union as an outcome variable (as compared to being in an opposite-sex union); the results are displayed as average marginal effects (AME). We estimated three models: the first only controlled for migrant status; the second added individual characteristics; and the third added couple characteristics. As the sample size is very small and the Microcensus requires a minimum number of cases for the respective cells ${ }^{2}$, we show the results for the upper boundary of same-sex couples and the upper boundary of migrants.

\section{Results}

Prevalence and reporting type

We start by presenting our results regarding our first hypothesis; i.e., that lower percentages of immigrants than of natives are in a same-sex union. Table 1 gives an overview of the total sample and the changes in the sample depending on the different concepts of "reporting type" and "migrant status". Section (a) shows how the number and the share of same-sex unions varies by "reporting"; with the lower boundary for valid answers only, and the upper boundary for answers that could be wrong, but that suggest a possible same-sex union. Section b) shows the lower and the upper boundary of migrants in the sample. Consequently, the number of same-sex unions and the number of migrants increased as how we define them widens.

We calculated the share of migrants in same-sex unions for the lower and the upper boundaries of migrants along the boundaries of the reporting type (Table 2). In the very restrictive definition of migrants, we found for the lower boundaries of reporting samesex unions a share of $0.3 \%$ to $0.4 \%$ of migrants in same-sex unions and a share of $0.6 \%$ of natives in same-sex unions. In the upper boundary of the reporting type, this share grew to $1.5 \%$ for migrants and to $1.9 \%$ for natives. If we use the wider definition of migrant status, the share of migrants in the lower boundaries of reporting remained at $0.3 \%$, and grew to $1.4 \%$ in the upper boundary. The share of same-sex unions for migrants and natives did not change based on the use of a wider or a more restrictive definition of migrant status, as the number of natives in same-sex unions was always higher than the number of migrants in these unions. Furthermore, the share of samesex unions for natives and migrants only became noticeable in the upper boundary of the reporting type.

${ }^{2}$ It is required that case numbers and quantiles with less than three cases are kept secret (RDC, 2017). 
Table 1 Overview about the total sample by using different definitions for "reporting type" and "migrant status"

\begin{tabular}{|c|c|c|c|c|c|}
\hline a) "Reporting type" & $N$ & $N$ same sex & $\%$ same sex & Boundary & \\
\hline Valid answers, main residence & 158,762 & 904 & 0.6 & Lower & \\
\hline $\begin{array}{l}\text { + Valid answers, secondary residence/ } \\
\text { commuters }\end{array}$ & 163,210 & 993 & 0.6 & & \\
\hline + Missing/imputed answers & 163,229 & 997 & 0.6 & & \\
\hline + Possible wrong answers & 165,318 & 3084 & 1.9 & Upper & \\
\hline b) "Migrant status" & $N$ "migrant" & \% "migrant" & $N$ "native" & $\%$ "native" & Boundary \\
\hline $\begin{array}{l}\text { First generation, } \\
\text { foreign nationality }\end{array}$ & 14,282 & 8.6 & 151,036 & 91.4 & Lower \\
\hline $\begin{array}{l}\text { + First generation, } \\
\text { German nationality }\end{array}$ & 29,257 & 17.7 & 136,061 & 82.3 & \\
\hline $\begin{array}{l}\text { + Second generation, } \\
\text { foreign nationality }\end{array}$ & 30,667 & 18.6 & 134,651 & 81.4 & \\
\hline $\begin{array}{l}\text { + Second generation, } \\
\text { German nationality }\end{array}$ & 32,935 & 19.9 & 132,383 & 80.1 & Upper \\
\hline
\end{tabular}

Source: Calculations based on German Micro census SUF $2013(N=165,318)$

In Fig. 1, we show the differences by sex. For the upper boundary of same-sex unions, we found that $1.5 \%$ of the migrant men and $1.9 \%$ of the native German men, and $2.0 \%$ of the native German women and $1.4 \%$ of the migrant women, were in a same-sex union. In the sample with imputations, as well as in the sample of those respondents who mentioned a secondary residence and living apart together, the shares of respondents who were in a same-sex union were substantially lower, at $0.6 \%$ of the native men and $0.4 \%$ of the migrant men, and at $0.7 \%$ of the native women and $0.2 \%$ of the migrant women. In the smallest sample, these shares were almost unchanged. Overall, we found that regardless of how same-sex unions are reported, same-sex partnerships were more common among natives than among migrants.

Table 2 Individuals in same-sex couples in Germany, by "reporting type" and "migrant status"

\begin{tabular}{|c|c|c|c|c|c|c|}
\hline & \multicolumn{3}{|l|}{ "Native" } & \multicolumn{3}{|l|}{ "Migrant" } \\
\hline & \% same sex & $N$ same sex & Total $N$ & \% same sex & $N$ same sex & Total $N$ \\
\hline \multicolumn{7}{|c|}{ a) Using "lower" boundaries for "migrant status" } \\
\hline Valid answers, main residence & 0.6 & 860 & 144,881 & 0.3 & 44 & 13,881 \\
\hline $\begin{array}{l}\text { + Valid answers, secondary residence/ } \\
\text { commuters }\end{array}$ & 0.6 & 941 & 149,091 & 0.4 & 52 & 14,119 \\
\hline + Missing/imputed answers & 0.6 & 945 & 149,108 & 0.4 & 52 & 14,121 \\
\hline + Possible wrong answers & 1.9 & 2,871 & 151,036 & 1.5 & 213 & 14,282 \\
\hline \multicolumn{7}{|c|}{ b) Using "upper" boundary for "migrant status" } \\
\hline Valid answers, main residence & 0.6 & 812 & 126,717 & 0.3 & 92 & 32,045 \\
\hline $\begin{array}{l}\text { + Valid answers, secondary residence/ } \\
\text { commuters }\end{array}$ & 0.7 & 890 & 130,648 & 0.3 & 103 & 32,562 \\
\hline + Missing/imputed answers & 0.7 & 894 & 130,664 & 0.3 & 103 & 32,565 \\
\hline + Possible wrong answers & 2.0 & 2,611 & 132,383 & 1.4 & 473 & 32,935 \\
\hline
\end{tabular}

Source: Calculations based on German Micro census SUF 2013 
Table 3 Bivariate statistics: Union type and exogamy (in \%)

\begin{tabular}{|c|c|c|c|c|c|c|}
\hline \multirow[t]{2}{*}{ A) "Migrant" } & \multicolumn{2}{|c|}{ Exogamy } & \multicolumn{2}{|c|}{ Endogamy } & \multicolumn{2}{|c|}{ Total } \\
\hline & $\%$ & $N$ & $\%$ & $N$ & $\%$ & $N$ \\
\hline \multicolumn{7}{|c|}{ Lower boundary for "reporting type $e^{\prime * * * *}$} \\
\hline Opposite-sex unions & 21.9 & 6,989 & 78.1 & 24,964 & 99.7 & 31,953 \\
\hline Same-sex unions & 65.2 & 60 & 34.8 & 32 & 0.3 & 92 \\
\hline \multicolumn{7}{|c|}{ Upper boundary for "reporting type $e^{\prime * * * *}$} \\
\hline Opposite-sex unions & 22.3 & 7238 & 77.7 & 25224 & 98.6 & 32,462 \\
\hline Same-sex unions & 23.0 & 109 & 77.0 & 364 & 1.4 & 473 \\
\hline \multirow[t]{2}{*}{ B) “Native” } & \multicolumn{2}{|c|}{ Exogamy } & \multicolumn{2}{|c|}{ Endogamy } & \multicolumn{2}{|c|}{ Total } \\
\hline & $\%$ & $N$ & $\%$ & $N$ & $\%$ & $N$ \\
\hline \multicolumn{7}{|c|}{ Lower boundary for "reporting type $e^{\prime * * * *}$} \\
\hline Opposite-sex unions & 5.6 & 6,989 & 94.4 & 118,916 & 99.4 & 125,905 \\
\hline Same-sex unions & 7.4 & 60 & 92.6 & 752 & 0.6 & 812 \\
\hline \multicolumn{7}{|c|}{ Upper boundary for "reporting type"**** } \\
\hline Opposite-sex unions & 5.6 & 7238 & 94.4 & 122534 & 98.0 & 129,772 \\
\hline Same-sex unions & 4.2 & 109 & 95.8 & 2502 & 2.0 & 2611 \\
\hline
\end{tabular}

Source: Calculations based on German Micro census SUF $2013\left(N_{\text {lower boundary }}=158,762 ; N_{\text {upper boundary }}=165,318\right)$ Note: $\mathrm{Chi}^{2}$ distribution test is significant with $p<0.001$. Using "upper boundary" for "migrant status"

In our second hypothesis, we shed light on the question of whether there is an association between same-sex unions and exogamous unions (Table 3). We found for migrants that in the lower boundary for same-sex unions, $65 \%$ of the same-sex unions were exogamous unions and $35 \%$ endogamous unions, while $22 \%$ of the opposite-sex unions were exogamous unions with a native. On the native side at the lower boundary, we found that $7 \%$ of the same-sex unions and $6 \%$ of the opposite-sex unions were exogamous unions.

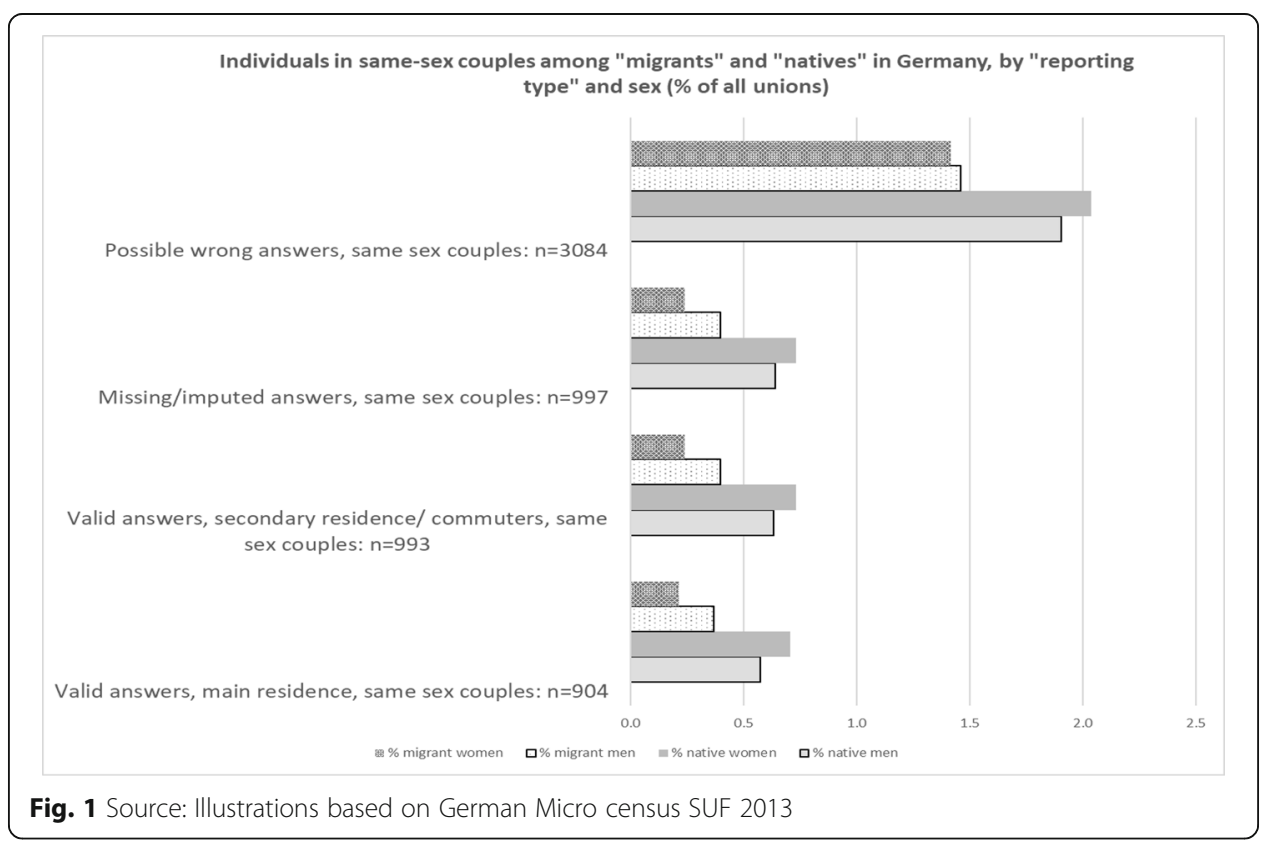


For the upper boundary of the reporting type the results change (Table 3). We found that the share of exogamous unions in same-sex unions for migrants was still higher, but declined to $23 \%$, while the share in opposite-sex unions remained almost unchanged. For natives, the share of exogamous same-sex unions declined to $4 \%$. We also carried out similar analyses for the sample with the lower boundary for migrant status and found similar exogamy prevalence for migrants. For natives, however, the exogamy rate was higher in both same-sex and opposite-sex unions when we used the wider definition of migrant, indicating that partners of natives belong to the first migrant generation (corresponding to our lower boundary for migrant status) and to the second generation (our upper boundary). (Note: we do not show these results because of the small sample size).

\section{Individual patterns and couple characteristics}

In this second part of our results, we present the individual patterns and the couple characteristics of same-sex couples (testing our third hypothesis), and briefly review our multivariate analysis. Tables 4 and 5 compare the bivariate statistics of same-sex migrant couples, migrants in an endogamous and an exogamous union, and native same-sex couples, by sex.

We found that migrant women in a same-sex couple tended to be younger than migrant women in an opposite-sex couple (Table 4). Almost $40 \%$ of the migrant women in samesex unions were between 18 and 35 years old; a share that was even higher than that for native women in a same-sex union. Furthermore, the ages of almost $90 \%$ of the migrant women in same-sex unions did not differ from those of their partners, in line with the share found for native women in same-sex unions. In opposite-sex unions, no age differences between the partners can be found only for about half of the migrant women.

We noted more similarities between migrant women in same-sex unions and natives in terms of educational level. Migrants in an exogamous union were more similar to migrants in a union with another migrant, as over $40 \%$ of women had a secondary or higher education level, while the share of migrant women in opposite-sex unions with this level of education was around $30 \%$. Again, heterogamy within the couple was less pronounced for same-sex unions, with $80 \%$ of the migrant women and $77 \%$ of the native women having the same educational level as their partner, while this share was 10 to 15 percentage points lower for migrants in opposite-sex unions.

Over the half of the migrant women in same-sex couples as well as in oppositesex couples were from European countries. Among women in same-sex and exogamous unions, the share who came from EU countries was higher, while among women in endogamous unions, the share who came from non-EU member states was higher. Overall, among migrant women in unions, the shares who came from Eastern European countries, member states, and non-member states were higher. The share of women in unions who came from MENA countries was one-third among those in endogamous opposite-sex couples, around 18\% among those in same-sex unions, and only $5 \%$ among those in opposite-sex mixed unions. There were no huge differences in citizenship between women in same-sex unions and in opposite-sex unions.

The occupational status of migrant women in a same-sex union was similar to the status of migrant women in a mixed union (for both groups, we find that half were in 


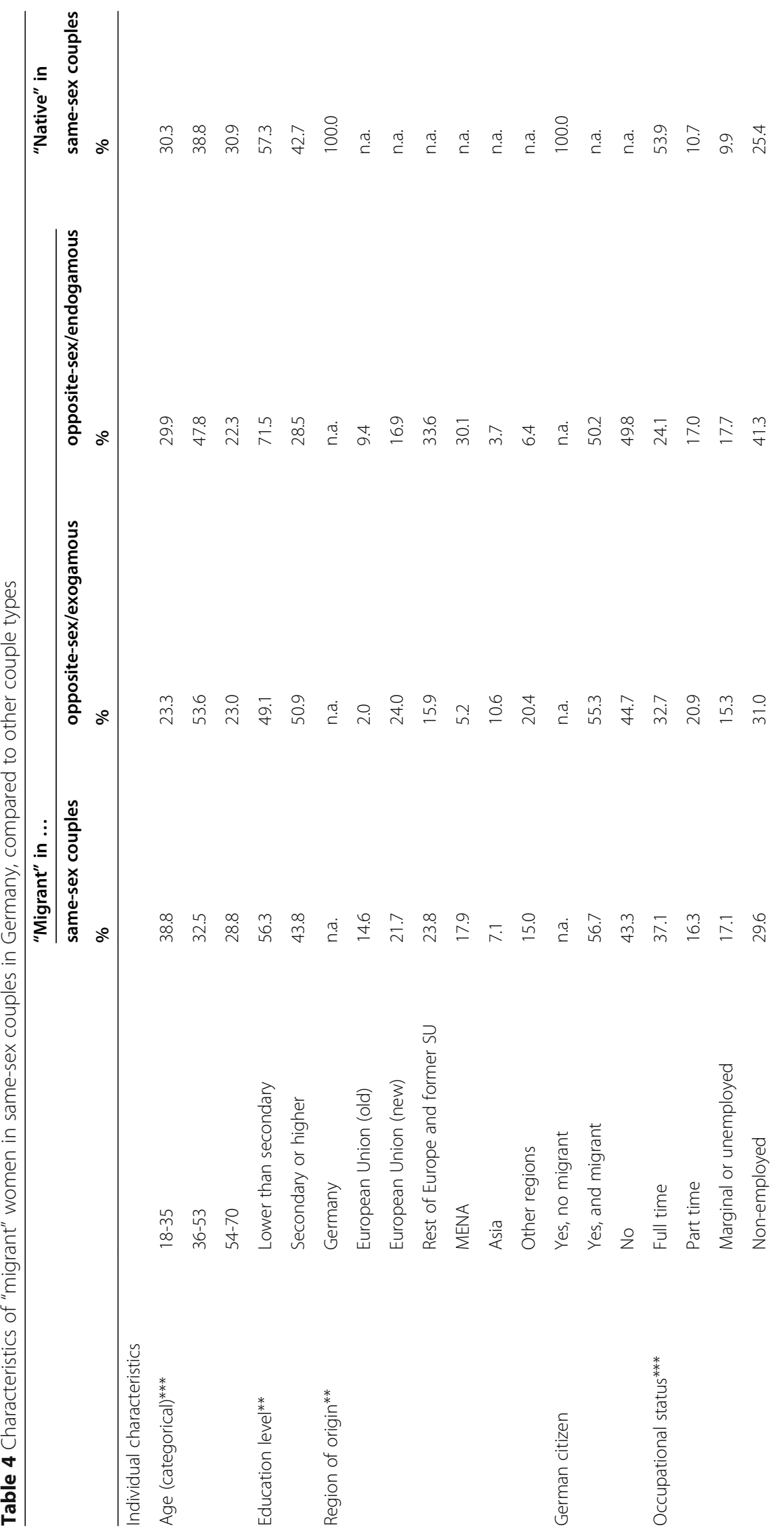




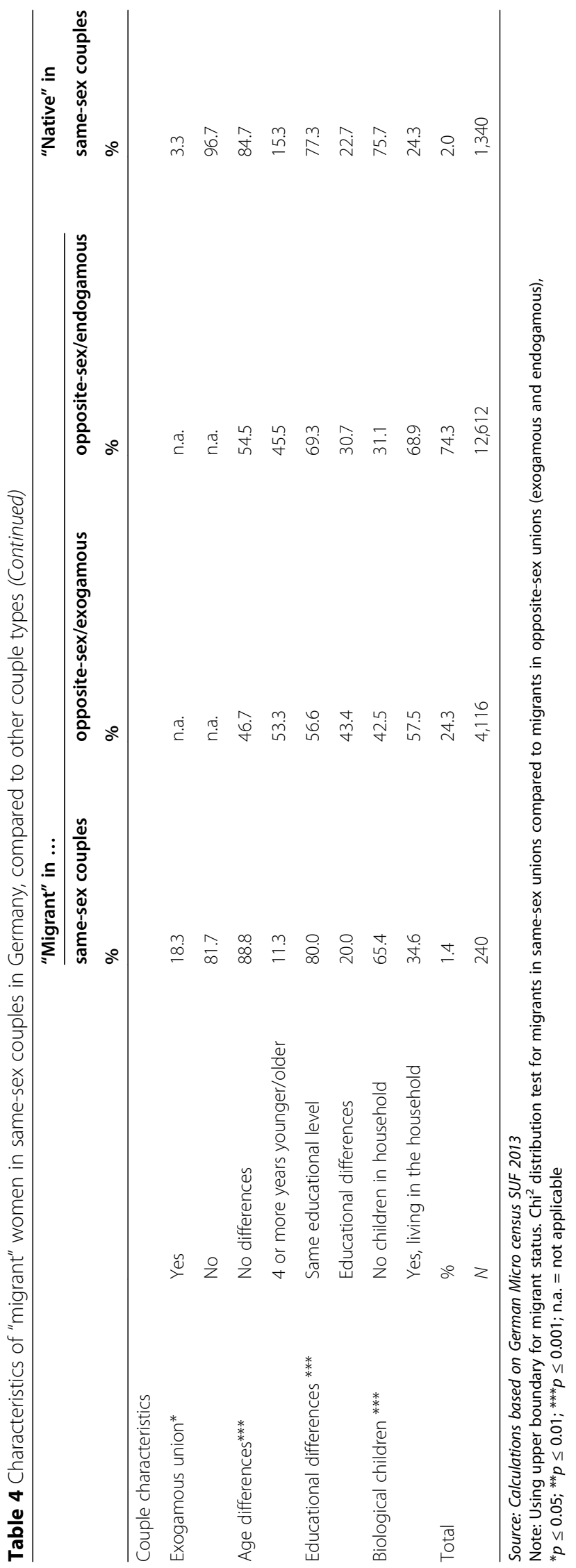




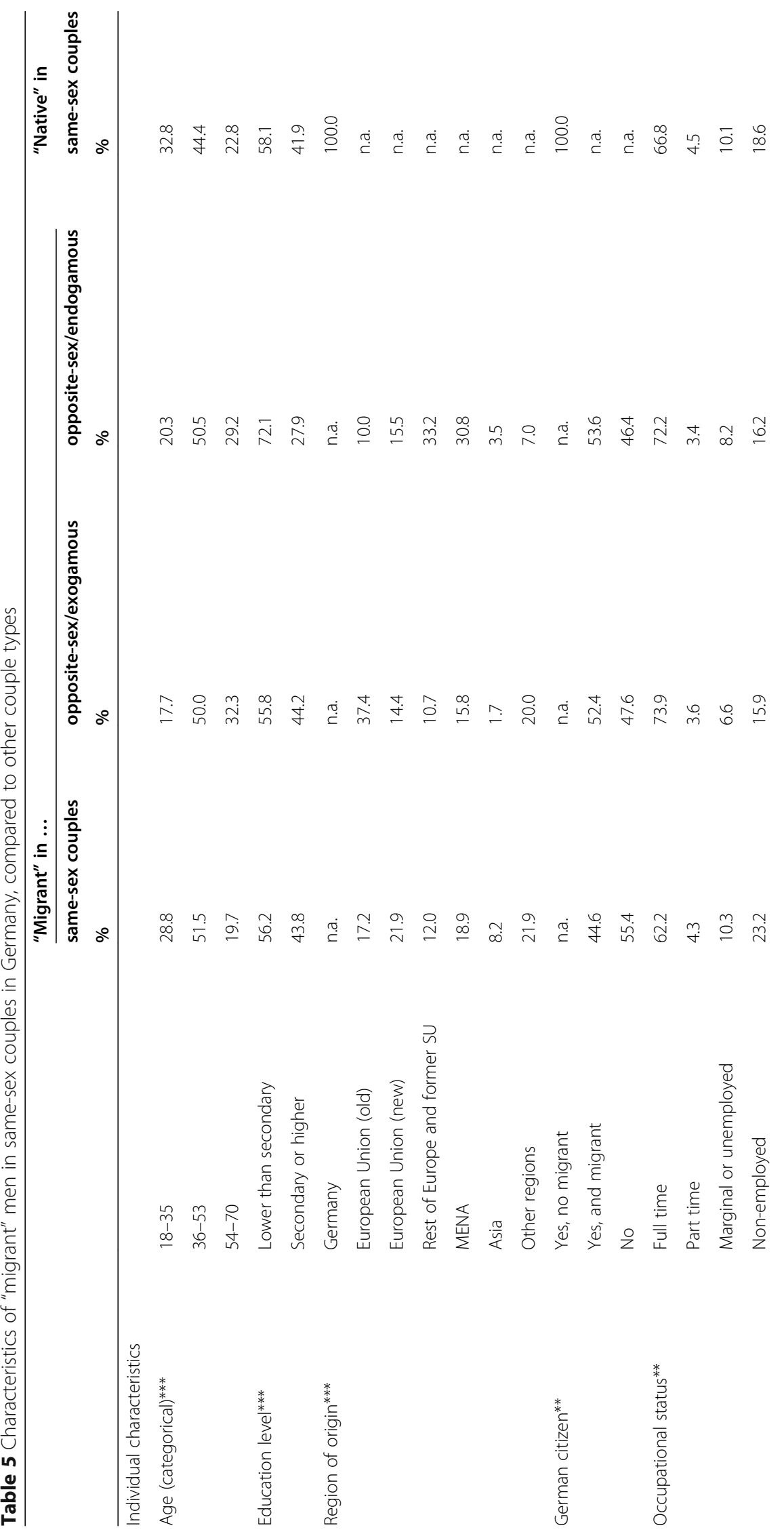




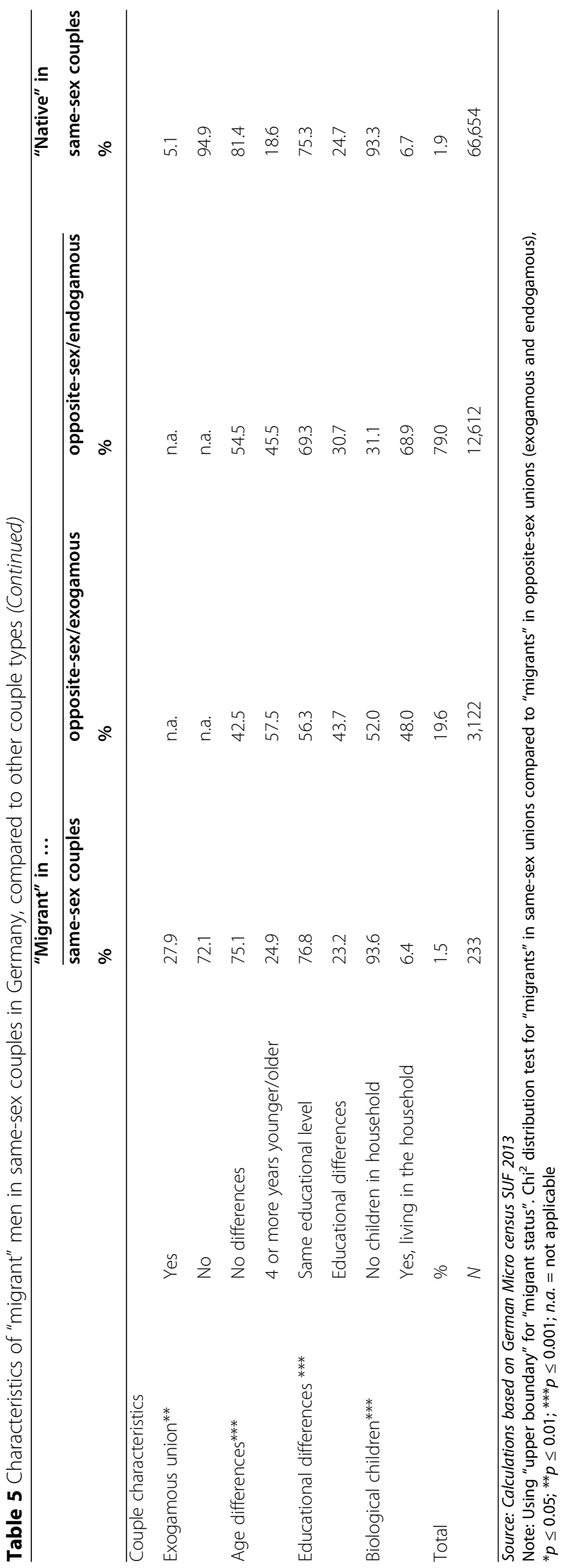


part- or full-time employment). These women were more likely to be employed than migrant women in a union with another migrant ( $41 \%$ were in part- or full-time employment), but were less likely to be employed than native German women in a samesex union (almost two-thirds were in part- or full-time employment).

Among men (Table 5), we find that migrantsin a same-sex union were younger than migrants in an opposite-sex union, with $29 \%$ of the former but less than $20 \%$ of the latter being under 36 years old. Thus, migrant men in a same-sex union were more like native men in a same-sex union, around one-third of whom were between 18 and 35 years old. However, we found that migrant men in a same-sex union were older than their female counterparts. Again, age differences were less common in same-sex unions than in opposite-sex unions for migrant men. Migrant men in same-sex unions were more likely to be similar in age than native men in same-sex unions. However, at $75 \%$, this share was not as high as it is for migrant women.

Similar to the pattern observed among women, we found that migrant men in a same-sex union had more often a secondary or higher level of education $(44 \%)$ than migrant men in an endogamous opposite-sex union (28\%), and were like men in exogamous unions (44\%) or natives in same-sex unions (42\%).

Migrant men in same-sex unions, like native men in same-sex unions, were less likely to report having a different educational level than their partner (23\%) than migrant men in opposite-sex unions, $31 \%$ and $44 \%$ of whom had a different educational level than their partner.

The share of migrants from Europe was similar to that of women migrants from the European Union. However, in same-sex unions, the share of migrants from other European countries was lower; at $12 \%$, while the share of migrants from other regions was higher, at $22 \%$. Again, we found that a mixed union was more common for migrants from old European member countries, while for same-sex unions and opposite-sex endogamous unions, the region of origin was more likely to lie in Eastern Europe. In contrast to migrant women, migrant men were less likely to be German citizens (45\%) if they were in same-sex unions, while they were more likely to be German citizens if they were in opposite-sex unions.

Migrant men in a same-sex union had lower levels of labor market participation than all of the other men in our sample. Around one-third of the migrant men in a samesex union were marginally employed, unemployed, or non-employed. For the other groups, this share was around one-fourth to one-fifth, with native men in a same-sex union having the second-lowest level of labor market participation ( $71 \%$ in full- or part-time employment).

To end our bivariate description, we want to mention children living in the household. We found, perhaps not surprisingly, that people in a same-sex union, regardless of whether they were migrants or natives, were less likely to be living with one or more children in the household than women and men in an opposite-sex union. However, the differences between respondents who were sharing a household with children were higher among women than among men: $24 \%$ of native and $35 \%$ of migrant women, but only $6 \%$ of native and $7 \%$ of migrant men, were living with one or more children.

In the appendix, we prepared a table for first multivariate statistics (Table 6 in Appendix) by estimating a logistic regression in three steps. In the first step, we looked at whether there is an effect of migrant status on the probability of being in a same-sex 
union, and we found that migrants were significantly less likely than natives to be in a same-sex union. This result remained highly significant after controlling for further individual variables and couple characteristics. Migrants had a 1\%-point lower likelihood of being in a same-sex union. Most importantly, we could investigate in more detail the question of whether social boundary crossing with respect to sexual preferences is also associated with crossing the "national" boundary. The results of our multivariate analyses did not support this assumption. Instead, we found overall that those individuals who were in an exogamous union were also less likely to be in a same-sex union.

\section{Discussion and conclusions}

Our study explored the intersection of international migration and sexual preference by shedding light on same-sex unions among migrants. Against the backdrop of growing ethnic diversity and greater social and legal liberality toward non-normative living arrangements, our main aim was to examine the prevalence of migrants in same-sex unions and the socio-demographic patterns of these couples in Germany. Therefore, we compared them to migrants in opposite-sex unions and natives in same-sex unions in order to look at exogamy in terms of the migrant status of the partner in this comparison.

Before we conclude and discuss our results, we want to mention some limitations of our study. There may be an underestimation or an overestimation of the same-sex couples in our data. As other research has shown and as we mentioned above, the reporting type of same-sex couples could affect the results. For this reason, we calculated a range of estimates. Furthermore, we had information about existing unions only, and not about couples who divorced or split up. As a consequence, we may have underestimated those unions, especially given that Kolk and Andersson (2020) showed that same-sex unions have a higher risk of divorce than opposite-sex unions. In this respect, same-sex unions were again found to be similar to mixed unions, which also have a higher risk of divorce than endogamous unions (Milewski and Kulu, 2014). In addition, we were only able to identify same-sex unions based on the reported binary category of "sex" and sexual behavior, as we had no information about the respondents' sexual identities. Therefore, transgender or intersexual individuals, as well as bi-sexual men and women, and their specific intersections regarding diversity, could not be identified in our study. Additionally, as the German Microcensus consists of household observations, we had no information about the unions of people who were living apart together if the respondents did not want to give this information. Because we had no information about sexual orientations, we were also unable to determine how many of the people-and especially of the single people-we dropped would have preferred to be living in a same-sex union. Moreover, as we could not distinguish further between different migrant generations, we could not determine how different the boundaries between the first- and second-generation migrants and the natives were (Alba, 2005). We cannot say why we find differences between migrants and natives. Migrants may have tried to avoid being identified as being in a same-sex union because of the possible disadvantages or pressures by third parties, like their families, that would be associated with doing so. Alternatively, the share of migrants in same-sex unions may simply be de facto smaller. We did not include marital status in our analyses, although it could give information about the institutionalization of these unions. But marriage was not 
an option for same-sex couples in Germany in 2013, when the data we used were collected. At that time, same-sex unions could only be institutionalized as a registered partnership. Furthermore, as we use in the upper boundary these registered unions as well as potential couples, the differences in the institutionalization of a union would be naturally influenced by our treatment of potential couples. We have kept these limitations and the exploratory nature of our study in mind in our discussion of the results. In this study, we first looked at the share of same-sex unions among migrants and natives in Germany, and second at the differences and similarities in the individual and couple characteristics of migrants in a same-sex union, migrants in an opposite-sex union, and natives in a same-sex union.

In our first hypothesis, we assumed that the percentage of individuals in a samesex union would be lower among immigrants than among natives. We found support for this assumption, because in all of our calculations, we found that more natives than migrants were in a same-sex union. We further found that migrant men were more likely than migrant women to be in a same-sex union. Another finding is that migrants in same-sex unions are more likely to be with a partner who comes from a European country than from another region. We should note that we have only examined the same-sex unions that are visible because the partners are living together or have institutionalized the union. Living openly as a same-sex couple is less common or even criminalized in some regions in the world. However, this does not automatically mean that there are fewer LGBT people in these regions, or that the behavior always matches the norms in the country of origin (Bauer, 2018: p. 79). Therefore, this finding should not be overestimated. Furthermore, the acculturation process and the declining influence of the region of origin should also be mentioned (Röder 2015). The situation is more complex, as it is not only about the migrants' country of origin, but about the host society: i.e., how migrants become part of and feel about the host society, and what influences their attitudes (Röder and Lubbers 2016). In addition, our results showed that the shares of respondents who were in a same-sex union evolved in the same direction in our calculations among natives and immigrants.

We can neither reject nor support straightforwardly our second hypothesis about a positive association of same-sex unions and exogamy. On the one hand, we detected for the lower-boundary sample that same-sex unions are more likely to be exogamous unions of migrants and natives. This could mean that when one social boundary has been crossed, it becomes easier to cross another boundary. On the other hand, we cannot find such a clear pattern for the upper boundary of reporting types. What could be the reason for such a difference? First, this discrepancy may be related to the reporting type. In the sample with the lower boundary, where we may underestimate the number of same-sex unions, we found mainly institutionalized unions. Such an "institutionalization" may occur more frequently in exogamous unions as a consequence of the migrant partner acquiring a residence permit. In the sample with the upper boundary, where we may overestimate the number of same-sex unions, we may count more living arrangements which are not based on an intimate relationship, and which may have more homogenous socio-demographic characteristics for other reasons, such as a flat share for tertiary education. A second explanation for why we found more exogamy in the lower- 
boundary sample may be related to the LGBT movement itself. There are a lot of similarities in the political organizations of LGBT people around the world (Adam et al. 1999), and the community members have many cross-border contacts. Hence, the LGBT subculture may have the function of an internationalized partner market in which individuals from one country meet and mate with people from other countries. Moreover, migration and union formation are endogenous processes. Migrants get into contact with natives in Germany, and some may move to Germany and form unions with their partner. This may also explain why exogamy is higher in native same-sex couples than in opposite-sex couples in the lower-boundary sample. By contrast, if a migrant of the second generation born in Germany is in a union with a first-generation migrant, we would not define this as an exogamous union (as a union between a native and a migrant), but as an endogenous union between two migrants, because we use here the wider definition of "migrant background".

The individual patterns and couple characteristics we uncovered supported our third hypothesis, as we found that migrants in a same-sex union were younger and better educated than other groups. However, the findings for employment were not as clear as we expected them to be. When we looked at the couple level, we found that same-sex unions were more homogenous than opposite-sex unions, and were more similar to the same-sex unions of natives.

Overall, we found that migrants in a same-sex union constituted a group that was distinct from that of migrants in an opposite-sex union. In the context of the differences between men and women, and the similarities to the group of natives in a same-sex union, we could describe migrants in a same-sex union as a small group, thereby calling into question classical ideas of immigrants in host societies. On the one hand, these migrants may be subject to double discrimination; and on the other hand, they are part of the processes of liberalization and increasing diversity that have been taking place in western society. Future research should take up again the contradictory evidence for the association of exogamy and same-sex unions, as both reflect the changes in the societal climate.

To conclude, we found that the patterns of migrants in a same-sex union were similar to those of natives in a same-sex union and of migrants in an exogamous union, and that they differed from those of migrants in an opposite-sex union with another migrant. We further showed that the number of individuals in a same-sex union was low, and was even lower among migrants than among natives. As we described above, both same-sex unions and migration are still sensitive topics, and when they interconnect, they represent an even more sensitive group. With this study, we contribute to LGBT topics in the twenty-first century by providing the first quantitative presentation of this minorityin-the-minority group in Germany. Future research should take into account that migration is an action that is taken not only by individuals who prefer to be in an opposite-sex union. Furthermore, it is important to recognize that migrants' experiences of discrimination in their context of origin and in their host society may influence their day-to-day life and could generate special needs associated with the similarities and dissimilarities between these migrants and migrants in an opposite-sex union and natives in a same-sex union. 


\section{Appendix}

Table 6 Results of logistic regression models

\begin{tabular}{|c|c|c|c|c|c|c|c|}
\hline \multicolumn{2}{|c|}{ Dependent variable: Same-sex union (no (0)/ yes (1)) } & \multicolumn{2}{|c|}{$\begin{array}{l}\text { Model 1: } \\
\text { Migrant status }\end{array}$} & \multicolumn{2}{|c|}{$\begin{array}{l}\text { Model 2: } \\
\text { Individual } \\
\text { characteristics }\end{array}$} & \multicolumn{2}{|c|}{$\begin{array}{l}\text { Model 3: } \\
\text { Couple } \\
\text { characteristics }\end{array}$} \\
\hline & & AME & $p$ value & AME & $p$ value & AME & $p$ value \\
\hline "Migrant" & Yes (ref.: "native") & -0.01 & $<0.001$ & -0.01 & $<0.001$ & -0.01 & $<0.001$ \\
\hline Sex & Women (ref.: men) & & & $<0.01$ & 0.227 & $<0.01$ & 0.900 \\
\hline \multirow{2}{*}{$\begin{array}{l}\text { Birth cohort } \\
\text { (ref.: 1960-1977) }\end{array}$} & 1943 to 1959 & & & $<0.01$ & $<0.001$ & $<0.01$ & $<0.001$ \\
\hline & 1978 to 1995 & & & 0.03 & $<0.001$ & 0.03 & $<0.001$ \\
\hline Educational level & $\begin{array}{l}\text { Secondary or higher (ref:: lower than } \\
\text { secondary level) }\end{array}$ & & & $<0.01$ & 0.005 & $<0.01$ & 0.005 \\
\hline $\begin{array}{l}\text { Exogamous } \\
\text { union }\end{array}$ & Yes (ref.: no) & & & & & -0.00 & 0.048 \\
\hline Age differences & $\begin{array}{l}\text { No differences (ref.: } 4 \text { or more years } \\
\text { younger/older) }\end{array}$ & & & & & 0.02 & $<0.001$ \\
\hline $\begin{array}{l}\text { Educational } \\
\text { differences }\end{array}$ & $\begin{array}{l}\text { Same level (ref.: educational } \\
\text { differences) }\end{array}$ & & & & & 0.01 & $<0.001$ \\
\hline \multicolumn{2}{|l|}{ N } & \multicolumn{2}{|l|}{165,318} & \multicolumn{2}{|l|}{165,318} & \multicolumn{2}{|l|}{165,318} \\
\hline \multicolumn{2}{|l|}{ Nagelkerke $R^{2}$} & \multicolumn{2}{|l|}{0.002} & \multicolumn{2}{|l|}{0.033} & \multicolumn{2}{|l|}{0.072} \\
\hline
\end{tabular}

Source: Calculations based on German Micro census SUF 2013

Note: All models estimated for the upper boundary of same-sex unions and for the definition of migrants as persons who moved to Germany or who were born as the (grand) child of at least one parent who was not born in Germany

\section{Acknowledgements}

We thank two anonymous reviewers for their constructive discussion of our research project and their helpful comments on the paper, as well as Miriam Hils for language editing.

\section{Authors' contributions}

Conceptualization: MKB NM. Data preparation and formal analysis: MKB. Funding acquisition: NM. Writing: MKB NM. All authors have read and approved the final manuscript.

\section{Funding}

The work of the first author was funded by a doctoral research grant within the THEORIA program of the Federal State Mecklenburg Western Pomerania, acquired by the second author ("Exogamous unions with immigrants in Germany", grant number THEORIA-UR21). Open access funding provided by Projekt DEAL.

\section{Availability of data and materials}

The data used in our study are available from the Research Data Centers of the Federal Statistical Office and Statistical Offices of the Federal States in Germany upon request at the Research Data Centers (the access to the data is regulated by law).

\section{Competing interests}

The authors declare that they have no competing interests.

Received: 30 April 2020 Accepted: 2 September 2020

Published online: 06 October 2020

\section{References}

Adam, B. D., Duyvendak, J. W., \& Krouwel, A. (1999). Gay and lesbian movements beyond borders? National imprints of a worldwide movement. In B. D. Adam, J. W. Duyvendak, \& A. Krouwel (Eds.), The global emergence of gay and lesbian politics. National imprints of a wordlwide movement (pp. 344-371). Temple University Press.

Adamczyk, A., Boyd, K. A., \& Hayes, B. E. (2016). Place matters: Contextualizing the roles of religion and race for understanding Americans' attitudes about homosexuality. Social Science Research, 57, 1-16. https://doi.org/10.1016/j.ssresearch.2016.02.00

Adamczyk, A., \& Pitt, C. (2009). Shaping attitudes about homosexuality: The role of religion and cultural context. Social Science Research, 38(2), 338-351. https://doi.org/10.1016/j.ssresearch.2009.01.002

Alba, R. (2005). Bright vs. blurred boundaries: Second-generation assimilation and exclusion in France, Germany, and the United States. Ethnic and Racial Studies, 28(1), 20-49. https://doi.org/10.1080/0141987042000280003

Alba, R., \& Nee, V. (1997). Rethinking assimilation theory for a new era of immigration. The International Migration Review, 31(4), 826-874. https://doi.org/10.2307/2547416

Almond, G. A., \& Verba, S. (1989). The civic culture: Political attitudes and democracy in five nations. Newbury Park: Sage Publications. 
Andersen, R., \& Fetner, T. (2008). Economic inequality and intolerance: Attitudes toward homosexuality in 35 democracies. American Journal of Political Science, 52(4), 942-958. https://doi.org/10.1111/j.1540-5907.2008.00352.x

Andersson, G., Noack, T., Seierstad, A., \& Weedon-Fekjaer, H. (2006). The demographics of same-sex marriages in Norway and Sweden. Demography, 43(1), 79-98. https://doi.org/10.1353/dem.2006.0001

Ayoub, P. M., \& Garretson, J. (2017). Getting the message out: Media context and global changes in attitudes toward homosexuality. Comparative Political Studies, 50(8), 1055-1085. https://doi.org/10.1177/0010414016666836

Bail, C. A. (2008). The configuration of symbolic boundaries against immigrants in Europe. American Sociological Review, 73(1), 37-59. https://doi.org/10.1177/000312240807300103

Banens, M., \& Le Penven, E. (2016). Sex miscoding in the census and its effects on the enumeration of same-sex couples. Population, 71(1), 131-143.

Bauer, T. (2018). Die Vereindeutigung der Welt: Über den Verlust an Mehrdeutigkeit und Vielfalt. Ditzingen: Reclam.

Beck, U., \& Beck-Gernsheim, E. (2005). Das ganz normale Chaos der Liebe, (13th ed., ). Suhrkamp: Frankfurt am Main.

Becker, G. S. (1973). A theory of marriage: Part I. Journal of Political Economy, 81(4), 813-846. https://doi.org/10.1086/260084

Black, D., Gates, G., Sanders, S., \& Taylor, L. (2000). Demographics of the gay and lesbian population in the United States: Evidence from available systematic data sources. Demography, 37(2), 139-154. https://doi.org/10.2307/2648117

Brumbaugh, S. M., Sanchez, L. A., Nock, S. L., \& Wright, J. D. (2008). Attitudes toward gay marriage in States undergoing marriage law transformation. Journal of Marriage and Family, 70(2), 345-359. https://doi.org/10.1111/j.1741-3737.2008.00486.x

Carol, S. (2013). Intermarriage attitudes among minority and majority groups in western Europe: The role of attachment to the religious in-group. International Migration, 51(3), 67-83. https://doi.org/10.1111/imig.12090

Carrillo, H. (2004). Sexual migration, cross-cultural sexual encounters, and sexual health. Sexuality Research \& Social Policy, 1(3), 58-70. https://doi.org/10.1525/srsp.2004.1.3.58

Celikaksoy, A., Nekby, L., \& Rashid, S. (2010). Assortative mating by ethnic background and education among individuals with an immigrant background in Sweden. Zeitschrift Für Familienforschung/Journal of Family Research, 22(1), 65-88.

Chamie, J., \& Mirkin, B. (2011). Same-sex marriage: A new social phenomenon. Population and Development Review, 37(3), 529-551. https://doi.org/10.1111/j.1728-4457.2011.00433.x

Chauvin, S., Robledo, M. S., Koren, T., \& Illidge, J. (2019). Class, mobility and inequality in the lives of same-sex couples with mixed legal statuses. Journal of Ethnic and Migration Studies, O(0), 1-17. https://doi.org/10.1080/1369183X.2019.1625137

Cherlin, A. J. (2004). The deinstitutionalization of American marriage. Journal of Marriage and Family, 66(4), 848-861. https:// doi.org/10.1111/j.0022-2445.2004.00058.x

Coleman, D. (2006). Immigration and ethnic change in low-fertility countries: a third demographic transition. Population and Development Review, 32(3), 401-446.

Cortina, C., \& Festy, P. (2014). Identification of same-sex couples and families in censuses, registers and surveys (Working Paper 8 (2014); Familes and Societies Working Paper Series, p. 27). Stockholm University.

Destatis, Federal Statistical Office. (2014). Mikrozensus 2013. Qualitätsbericht. Statistisches Bundesamt (Destatis).

Destatis, Federal Statistical Office. (2018). Bevölkerung und Erwerbstätigkeit Bevölkerung mit Migrationshintergrund - Ergebnisse des Mikrozensus 2017. Fachserie 1 Reihe 2.2, 2017. Statistisches Bundesamt (Destatis).

Eliason, M. J., \& Schope, R. (2007). Shifting sands or solid foundation? Lesbian, gay, bisexual, and transgender identity formation. In I. H. Meyer \& M. E. Northridge (Eds.), The health of sexual minorities: Public health perspectives on lesbian, gay, bisexual and transgender populations (pp. 3-26). New York: Springer US. https://doi.org/10.1007/978-0-387-31334-4_1

Eurostat. (2016). First and second-generation immigrants - Statistics on main characteristics. European Commission. https://ec. europa.eu/eurostat/statistics-explained/index.php/First_and_second-generation_immigrants__statistics_on_main_ characteristics\#General_overview. Accessed 29 Mar 2020.

Fassin, E., \& Salcedo, M. (2015). Becoming gay? Immigration policies and the truth of sexual identity. Archives of Sexual Behavior, 44(5), 1117-1125. https://doi.org/10.1007/s10508-015-0551-z

Festy, P. (2007). Numbering same-sex couples in censuses and population registers. Demographic Research, 17(12), 339-368. https://doi.org/10.4054/DemRes.2007.17.12

Fitzpatrick, J., Sharp, E. A., \& Reifman, A. (2009). Midlife singles' willingness to date partners with heterogeneous characteristics. Family Relations, 58(1), 121-133. https://doi.org/10.1111/j.1741-3729.2008.00539.x

FRA, European Union Agency for Fundamental Rights (2014). EU LGBT survey: European Union lesbian, gay, bisexual and transgender survey; main results. Publ. Off. of the Europ. Union.

Franchi, M., \& Selmi, G. (2020). Same-sex parents negotiating the law in Italy: Between claims of recognition and practices of exclusion. In M. Digoix (Ed.), Same-sex families and legal recognition in Europe (pp. 73-93). Springer International Publishing. https://doi.org/10.1007/978-3-030-37054-1_4

Gates, G. J. (2010). Same-sex couples in US Census Bureau data: Who gets counted and why (The Williams Institute Research Paper, p. 11). The Williams Institute.

Gates, G. J. (2011). How many people are lesbian, gay, bisexual and transgender? (p. 8) (The Williams Institute Research Paper, p. 8). The Williams Institute.

Geary, R. S., Tanton, C., Erens, B., Clifton, S., Prah, P., Wellings, K., Mitchell, K. R., Datta, J., Gravningen, K., Fuller, E., Johnson, A. M. , Sonnenberg, P., \& Mercer, C. H. (2018). Sexual identity, attraction and behaviour in Britain: The implications of using different dimensions of sexual orientation to estimate the size of sexual minority populations and inform public health interventions. PLOS ONE, 13(1), e0189607. https://doi.org/10.1371/journal.pone.0189607

Goldani, A. M., Esteve, A., \& Turu, A. (2013). Coming out in the 2010 Census: Same-sex couples in Brazil and Uruguay. Conference Paper - XXVII IUSSP International Population Conference, Busan, Korea.

Golembe, J., Leyendecker, B., \& Busch, J. (2019). Psychosoziale Lage und gesellschaftliche Teilhabe von LSBTI-Geflüchteten in Deutschland - Forschungsstand und Anwendungsmöglichkeiten für die Jugendhilfe. In K. Nowacki \& S. Remiorz (Eds.), Junge Geflüchtete in der Jugendhilfe: Chancen und Herausforderungen der Integration (pp. 123-138). Wiesbaden: Springer Fachmedien. https://doi.org/10.1007/978-3-658-26777-3_8

González-Ferrer, A., Obućina, O., Cortina, C., \& Castro-Martín, T. (2018). Mixed marriages between immigrants and natives in Spain: The gendered effect of marriage market constraints. Demographic Research, 39(1), 1-32. https://doi.org/10.4054/ DemRes.2018.39.1

Gordon, M. M. (1964). Assimilation in American life. In The role of race, religion, and national origins. New York: Oxford University Press. 
Gürbüz, S. (2016). Homosexualiät im Spiegel der rechtsgeschichtlichen Entwicklung. Freiburger Zeitschrift für Geschlechterstudien, 22(1), 99-113. https://doi.org/10.25595/989

Haider-Markel, D. P., \& Joslyn, M. R. (2005). Attributions and the regulation of marriage: Considering the parallels between race and homosexuality. PS: Political Science \& Politics, 38(2), 233-239. https://doi.org/10.1017/S1049096505056362

Herek, G. M., Chopp, R., \& Strohl, D. (2007). Sexual stigma: Putting sexual minority health issues in context. In I. H. Meyer, \& M. E. Northridge (Eds.), The health of sexual minorities: Public health perspectives on lesbian, gay, bisexual and transgender populations (pp. 171-208). New York: Springer US. https://doi.org/10.1007/978-0-387-31334-4_8

Huijnk, W., \& Liefbroer, A. C. (2012). Family influences on intermarriage attitudes: A sibling analysis in the Netherlands. Journal of Marriage and Family, 74(1), 70-85. https://doi.org/10.1111/j.1741-3737.2011.00882.x

Huijnk, W., Verkuyten, M., \& Coenders, M. (2010). Intermarriage attitude among ethnic minority and majority groups in the Netherlands: The role of family relations and immigrant characteristics. Journal of Comparative Family Studies, 41(3), 389414. https://doi.org/10.3138/jcfs.41.3.389

Inglehart, R. (1997). Modernization and postmodernization: Cultural, economic, and political change in 43 societies. Newbury Park: Princeton University Press.

Inglehart, R., \& Norris, P. (2003). Rising tide: Gender equality and cultural change around the world. Cambridge: Cambridge University Press.

Kalmijn, M. (1998). Intermarriage and homogamy: Causes, patterns, trends. Annual Review of Sociology, 24(1), 395-421. https:// doi.org/10.1146/annurev.soc.24.1.395

Kertzner, R. M. (2007). Developmental issues in lesbian and gay adulthood. In I. H. Meyer \& M. E. Northridge (Eds.), The health of sexual minorities: Public health perspectives on lesbian, gay, bisexual and transgender populations (pp. 48-64). New York: Springer US. https://doi.org/10.1007/978-0-387-31334-4_3

Kitzinger, C., \& Wilkinson, S. (1995). Transitions from heterosexuality to lesbianism: The discursive production of lesbian identities. Developmental Psychology, 31(1), 95-104. https://doi.org/10.1037/0012-1649.31.1.95

Kolk, M., \& Andersson, G. (2020). Two decades of same-sex marriage in Sweden: A demographic account of developments in marriage, childbearing, and divorce. Demography, 57(1), 147-169. https://doi.org/10.1007/s13524-019-00847-6

Kollman, K. (2013). The same-sex unions revolution in western democracies. International norms and domestic policy change. Manchester, New York: Manchester University Press.

Kroh, M., Kühne, S., Kipp, C., \& Richter, D. (2017). Einkommen, soziale Netzwerke, Lebenszufriedenheit: Lesben, Schwule und Bisexuelle in Deutschland. DIW-Wochenbericht, 84(35), 687-698.

Kulu, H., \& Hannemann, T. (2019). Mixed marriage among immigrants and their descendants in the United Kingdom: Analysis of longitudinal data with missing information. Population Studies, 73(2), 179-196. https://doi.org/10.1080/00324728.2018.1493136

Lamont, M., \& Mizrachi, N. (2012). Ordinary people doing extraordinary things: Responses to stigmatization in comparative perspective. Ethnic and Racial Studies, 35(3), 365-381. https://doi.org/10.1080/01419870.2011.589528

Lamont, M., \& Molnár, V. (2002). The study of boundaries in the social sciences. Annual Review of Sociology, 28, 167-195. https://doi.org/10.1146/annurev.soc.28.110601.141107

Lauer, S., \& Yodanis, C. (2010). The deinstitutionalization of marriage revisited: A new institutional approach to marriage. Journal of Family Theory \& Review, 2(1), 58-72. https://doi.org/10.1111/j.1756-2589.2010.00039.x

Lengerer, A., \& Bohr, J. (2019a). Gibt es eine Zunahme gleichgeschlechtlicher Partnerschaften in Deutschland? Theoretische Überlegungen und empirische Befunde. Zeitschrift Für Soziologie, 48(2), 136-157. https://doi.org/10.1515/zfsoz-2019-0010

Lengerer, A., \& Bohr, J. (2019b). Gleichgeschlechtliche Partnerschaften in Deutschland: Verbreitung, Entwicklung und soziale Unterschiede. Informationsdienst Soziale Indikatoren, 62, 7-12. https://doi.org/10.15464/isi.62.2019.7-12

Lengerer, A., \& Klein, T. (2007). Der langfristige Wandel partnerschaftlicher Lebensformenn im Spiegel des Mikrozensus. Wirtschaft Und Statistik, 4, 433-448.

Luibheid, E. P. (2008). Queer/migration: An unruly body of scholarship. GLQ, 14(2-3), 169-190. https://doi.org/10.1215/ 10642684-2007-029

Meyer, I. H. (2007). Prejudice and discrimination as social stressors. In I. H. Meyer \& M. E. Northridge (Eds.), The health of sexual minorities: Public health perspectives on lesbian, gay, bisexual and transgender populations (pp. 242-267). New York: Springer US. https://doi.org/10.1007/978-0-387-31334-4_10

Milewski, N., \& Kulu, H. (2014). Mixed marriages in Germany: A high risk of divorce for immigrant-native couples. European Journal of Population, 30(1), 89-113. https://doi.org/10.1007/s10680-013-9298-1

Norris, P., \& Inglehart, R. F. (2012). Muslim integration into Western cultures: Between origins and destinations. Political Studies, 60(2), 228-251. https://doi.org/10.1111/j.1467-9248.2012.00951.x

Nowok, B., Kupiszewska, D., \& Poulain, M. (2006). Statistics on international migration flows. In M. Poulain, N. Perrin, \& A. Singleton (Eds.), Towards harmonised European statistics on international migration, (pp. 203-231). Louvain-la-Neuve: Presses Universitaires de Louvain.

Padilla, M. B., Vasquez del Aguila, E., \& Parker, R. G. (2007). Globalization, structural violence, and LGBT health: A cross-cultural perspective. In I. H. Meyer \& M. E. Northridge (Eds.), The health of sexual minorities: Public health perspectives on lesbian, gay, bisexual and transgender populations (pp. 209-241). New York: Springer US. https:/doi.org/10.1007/978-0-387-31334-4_9

Phua, V. C., \& Kaufman, G. (1999). Using the census to profile same-sex cohabitation: A research note. Population Research and Policy Review, 18(4), 373-386. https://doi.org/10.1023/A:1006234713127

Ramirez-Valles, J. (2007). "I don't fit anywhere": How race and sexuality shape Latino gay and bisexual men's health. In I. H. Meyer \& M. E. Northridge (Eds.), The health of sexual minorities: Public health perspectives on lesbian, gay, bisexual and transgender populations (pp. 301-319). New York: Springer US. https://doi.org/10.1007/978-0-387-31334-4_12

RDC, RDC of the Federal Statistical Office and Statistical Offices of the Federal States (2013). German Microcensus (Scientific Use File)[Data Set]. RDC of the Federal Statistical Office and Statistical Offices of the Federal States.

RDC, RDC of the Federal Statistical Office and Statistical Offices of the Federal States. (2017). Regelungen zur Auswertung von Mikrodaten in den Forschungsdatenzentren der Statistischen Ämter des Bundes und der Länder (FDZ). Information und Technik Nordrhein-Westfalen.

Régnier-Loilier, A. (2018). Are the Generations and Gender Surveys well suited for studying same-sex couples? European Journal of Population, 34(4), 567-578 https://doi.org/10.1007/s10680-017-9440-6. 
Röder, A. (2015). Immigrants' attitudes toward homosexuality: socialization, religion, and acculturation in European host societies. International Migration Review, 49(4), 1042-1070. https://doi.org/10.1111/imre.12113

Röder, A., \& Lubbers, M. (2016). After migration: Acculturation of attitudes towards homosexuality among Polish immigrants in Germany, Ireland, the Netherlands and the UK. Ethnicities, 16(2), 261-289. https://doi.org/10.1177/ 1468796815616153

Rupp, M., \& Haag, C. (2016). Gleichgeschlechtliche Partnerschaften: Soziodemographie und Lebenspläne. In Y. Niephaus, M. Kreyenfeld, \& R. Sackmann (Eds.), Handbuch Bevölkerungssoziologie (pp. 327-345). Wiesbaden: Springer Fachmedien. https://doi.org/10.1007/978-3-658-01410-0_14

Serrano Amaya, J. F., \& Ríos González, O. (2019). Introduction to the special Issue: Challenges of LGBT research in the 21st century. International Sociology, 34(4), 371-381. https://doi.org/10.1177/0268580919856490

Soehl, T. (2017). From origins to destinations: Acculturation trajectories in migrants' attitudes towards homosexuality. Journal of Ethnic and Migration Studies, 43(11), 1831-1853. https://doi.org/10.1080/1369183X.2016.1246178

Steffens, M. C., \& Wagner, C. (2004). Attitudes toward lesbians, gay men, bisexual women, and bisexual men in Germany. Journal of Sex Research, 41(2), 137-149. https://doi.org/10.1080/00224490409552222

Steffens, M. C., \& Wagner, C. (2009). Diskriminierung von Lesben, Schwulen und Bisexuellen. In A. Beelmann \& K. J. Jonas (Eds. ), Diskriminierung und Toleranz: Psychologische Grundlagen und Anwendungsperspektiven (pp. 241-262). Wiesbaden: VS Verlag für Sozialwissenschaften. https://doi.org/10.1007/978-3-531-91621-7_12

Steinbugler, A. C. (2005). Visibility as privilege and danger: Heterosexual and same-sex interracial intimacy in the 21st Century. Sexualities, 8(4), 425-443. https://doi.org/10.1177/1363460705056618

Thibeaud, M. (2020). Same-sex families challenging norms and the law in France. In M. Digoix (Ed.), Same-sex families and legal recognition in Europe (pp. 95-115). Springer International Publishing. https://doi.org/10.1007/978-3-030-37054-1_5

Troy, A. B., Lewis-Smith, J., \& Laurenceau, J.P. (2006). Interracial and intraracial romantic relationships: The search for differences in satisfaction, conflict, and attachment style. Journal of Social and Personal Relationships, 23(1), 65-80. https:// doi.org/10.1177/0265407506060178

van de Kaa, D. J. (1987). Europe's second demographic transition. Population Bulletin, 42(1), 1-59.

Van Mol, C., \& de Valk, H. (2016). Migration and Immigrants in Europe: A historical and demographic perspective. In B. GarcésMascareñas \& R. Penninx (Eds.), Integration processes and policies in Europe: Contexts, levels and actors (pp. 31-55). Springer International Publishing. https://doi.org/10.1007/978-3-319-21674-4_3

Vasquez del Aguila, E. (2012). 'God forgives the sin but not the scandal': Coming out in a transnational context - between sexual freedom and cultural isolation: Sexualities. 15(2), 207-224. https://doi.org/10.1177/1363460711433751

Waaldijk, K. (2020). What first, what later? Patterns in the legal recognition of same-sex partners in European countries. In M. Digoix (Ed.), Same-sex families and legal recognition in Europe (pp. 11-44). Springer International Publishing. https://doi. org/10.1007/978-3-030-37054-1_2

Wagner, M., \& Valdés Cifuentes, I. (2014). Die Pluralisierung der Lebensformen-Ein fortlaufender Trend? Comparative Population Studies - Zeitschrift für Bevölkerungswissenschaft, 39(1), 73-98. doi: https://doi.org/10.12765/CPoS-2014-03de

\section{Publisher's Note}

Springer Nature remains neutral with regard to jurisdictional claims in published maps and institutional affiliations.

\section{Submit your manuscript to a SpringerOpen ${ }^{\circ}$ journal and benefit from:}

- Convenient online submission

- Rigorous peer review

- Open access: articles freely available online

- High visibility within the field

- Retaining the copyright to your article

Submit your next manuscript at $\boldsymbol{\nabla}$ springeropen.com 